\title{
Az európai integráció geopolitikai-geoökonómiai értelmezésének változása a kelet-közép-európai régióban az 1980-as évek végétől napjainkig
}

\author{
The geopolitical-geoeconomical importance of european integration in \\ East-Central Europe from the late eighties until now. \\ TöKÉs T ${ }^{1}$, ERDEY L ${ }^{2}$, Tóth $E^{3}$ NAGY $S^{4}$
}

Absztrakt.

1990 után a kelet-közép-európai országok helyzete geopolitikai és geoökonómia szempontból megváltozott. A rendszerváltozásnak köszönhetöen újra annak az Európának a részeivé váltak, melyböl a második világháború után a Szovjetunió kiszakitotta öket. A térség államai a rendszerváltozás utáni első évtizedben az európai integráció felé fordultak. 2004-ben megvalósult az Európai Unió keleti bővitése Európa újraegyesitése. A tagság bö első évtizede után elmondható, hogy a kelet-közép európai országok gazdasági és számos egyéb szempontból profitáltak a tagságból. Érdekeiket EU tagként sokkal eröteljesebben tudják érvényesiteni, mint belépésük elött. Azonban az integráció mélyitéséhez kapcsolódó hozzáállásuk átalakulóban van az elmúlt idöszakban. Megfogalmazódott az igény arra, hogy véleményüket hangsúlyosabban képviseljék. Ennek következtében a gazdasági integráció geopolitikai-geoökonómiai értelmezése a korábbi korszakoknál jóval széleskörübbé vált és esetenként jóval többet magában foglal, mint azt a hagyományos értelmezésböl következne.

Kulcsszavak: geoökonómia, Európai Unió, Kelet-Közép-Európa, rendszerváltozás, keleti bövités

Abstract.

Due to political reforms in 1990 the geopolitical and geoeconomical situation of the East-Central European countries has changed. In the very first years of the new political era these countries focused on the integration to the European Union. In 2004 the biggest accession ever opened the door to ten new member states resulting a more wider, more complex partnership in Europe. After a decade of their integration it was clear that East-Central European countries have benefited from the membership, in economical and many other ways. They can express their interests much stronger as

\footnotetext{
${ }^{1}$ Debreceni Egyetem, Gazdaságtudományi Kar, Világgazdasági- és Nemzetközi Kapcsolatok Intézet, tokes.tibor@econ.unideb.hu,

${ }^{2}$ Debreceni Egyetem, Gazdaságtudományi Kar, Világgazdasági- és Nemzetközi Kapcsolatok Intézet, erdey.laszlo@econ.unideb.hu,

${ }^{3}$ Debreceni Egyetem, Gazdaságtudományi Kar, Világgazdasági- és Nemzetközi Kapcsolatok Intézet, toth.eszter@econ.unideb.hu,

${ }^{4}$ Debreceni Egyetem, Gazdaságtudományi Kar, Világgazdasági- és Nemzetközi Kapcsolatok Intézet, nagy.sandor@econ.unideb.hu
} 
members of the EU then before their memberships. But their perception regarding deepening the integration is in change. There is a need to express their opinion much stronger. As a result, the geoeconomic interpretation of economic integration has become much broader in sense than in earlier periods, and sometimes involves far more thought than traditional interpretation.

Keywords: geoeconomy, European Union, East-Central Europe, regime change, Eastern enlargment of the $E U$

\section{Bevezetés}

Kelet-Közép-Európa a rendszerváltozás és az euroatlanti integráció kiteljesedése következtében átalakult. Ez az átalakulás nemcsak a régió országait, de magát az Európai Uniót illetve a tágabb értelemben vett Európát is érintette. A régió országai az 1990-es évek történéseinek köszönhetően kiléptek addigi viszonylagos elszigeteltségükből, melyet a szocialista blokk részeiként a Szovjetunió nyomására voltak kénytelenek elszenvedni. Az említett átalakulásnak köszönhetően a volt szocialista államok gazdasági integrációkhoz illetve az Európai Közösséghez való hozzáállása a nyolcvanas évektől napjainkig tartó időszakban többször is - ha olykor csak árnyalatnyi különbségekkel is - de változott. E változások befolyásolták a térség országainak viselkedését illetve hatással voltak azok tágabb környezetére, azaz az Európai Unió tagországaira is. Így a gazdasági integrációkhoz illetve az ehhez társított esetleges keleti nyitáshoz (vagyis az EU bővüléséhez) való hozzáállás nemcsak a térség országaiban, de az Európai Unió tagállamaiban is folyamatosan változott. A volt szocialista országok esetében a gazdasági integrációkkal kapcsolatos gondolkodás és az Európai Közösséghez füződő viszony többé-kevésbé három-öt történeti szakaszra osztható. A hármas fölosztás szocialista éra (1947-1989), rendszerváltozás-tagjelöltség (1989-2004), taggá válás (2004-2019) időszakokra bontható (Tőkés 2017). E hármas fölosztás kevésbé árnyalt, a finomabb különbségek és a jelenlegi kelet-közép-európai hozzáállás bemutatása szempontjából előnyösebb lehet öt időszak elkülönítése. Az öt korszak esetében az első szakasz a szocialista éra (19471989), a két világgazdaság fölfogásának időszaka. Ez, az az időszak, amikor a térség országai nem ismerték el valódi gazdasági integrációként a Közösséget vagy, ahogy akkor nevezték a Közös Piac országait. A második szakasz az enyhülés időszaka, azaz a 80 -as évek vége (19891994), amikor megtörténik a kapcsolatfelvétel a két blokk között. A harmadik szakasz a társulás illetve a tagjelöltség időszaka (1994-2004), amikor a térség országai elérendő célként tekintenek az Európai Integrációra. A negyedik szakasz a tagság első időszaka (2004-2010), amikor a keletközép-európai államok beilleszkednek a Közösségbe és annak teljes jogú tagjaivá válnak. Az ötödik szakasz a „kritikusabb hozzáállás ideje” vagyis a 2010-es évek elejétől napjainkig tartó időszak (2010-2018), amikor a régió országai egyre inkább felfedezik közös érdekeiket és azonosságaikat, melyekért hajlandóak közösen fellépni. Illetve eltérő történelmi gazdasági fejlődésüknek köszönhetően bizonyos kérdéseket másként látnak, mint a nyugat- vagy északeurópai országok és ezen eltérő véleményüket az elmúlt időszakban erőteljesebben hangoztatják. Természetesen az egyes szakaszok határai igen képlékenyek és akár országonként eltérhetnek, ám azt be kell látnunk, hogy a különböző szakaszok, ha nem is éles határokkal de megkülönböztethetők egymástól. Ha megvizsgáljuk e szakaszokat látható, hogy azok bizonyos eltéréseket mutatnak az adott időszak geopolitikai és geoökonómiai történéseinek függvényében. 
Így e szakaszok jól elemezhetők mind geopolitikai mind geoökonómiai szempontból. Az elemzés célja hogy általános képet adjon a kelet-közép-európai országok európai integrációhoz való hozzáállásáról melyet ezen államok mindenkori kormányzata és lakosságának véleménye erőteljesen befolyásolta. Az integrációk vizsgálata -geopolitikai és geoökonómiai szempontból is- komplex multidiszciplináris megközelítést igényel. Így az elemzés több tudományszakterület, (történelem, földrajz, közgazdaságtan, államelmélet, integrációelmélet, geopolitika) eredményeit használja föl.

\section{Az integráció geopolitikai-geoökonómiai értelmezése}

$\mathrm{Az}$ integrációknak számos értelmezése létezik, attól függően, hogy mely történelmi korszakot, mely tudományterületet vagy eszmetörténeti, politikai irányzatot vesszük figyelembe. Az integrációk kutatása csak a második világháború utáni időszaktól - az első sikeres integrációk megjelenésétől - került előtérbe, mégis alapjait már a klasszikus közgazdaságtan képviselőiinél Adam Smith-nél vagy David Ricardo-nál is megtaláljuk.

Az eredményesen múködő integrációs tömörülések (Európai Szabadkereskedelmi Társulás, Észak-Amerikai Szabadkereskedelmi Társulás) mind gazdasági alapokról indultak, és néhány esetben sikerült egyéb nem gazdasági típusú vívmányokat megvalósítani (Európai Unió). Azok, amelyek politikai vagy védelmi alapon próbálták megvalósítani az együttmüködést csekélyebb eredményeket értek el (Afrikai Egységszervezet, Afrikai Unió) vagy végül meg sem valósultak (Európai Védelmi közösség - EDC, Európai Politikai Közösség - EPC). A gazdasági integráció François Perroux meghatározása alapján „két vagy több gazdasági egység egyesülése egy bizonyos egészbe" (Perroux, 1954:419). A gazdasági integráció szintjeinek meghatározását Balassa Béla 1961-es, a gazdasági integráció elmélete című munkájához köthetjük. Eszerint többszintű egységesülési folyamatról van szó, mely folyamat szintjei egymásra rétegződnek (szabadkereskedelmi övezet, vámunió, közös piac, gazdasági unió, politikai unió) (Balassa, B. 1961). Palánkai Tibor szerint az integráció gazdasági értelemben „intenzív, tartós és hosszú távú, szervezett és intézményesített, az egész újratermelési folyamatot átfogó komplex munkamegosztásként határozható meg” (Palánkai 2011:79). Abban azonban a legtöbb szerző egyetért, hogy a gazdasági integrációk a gazdaság és a társadalom természetes fejlődése következtében jönnek létre, tehát kialakulásuk bizonyos idő és fejlettségi szint u tán szükségszerü következmény. A második világháború után világszerte több regionális gazdasági integráció bontakozott ki, melyek külön-külön eltérő célokat tüztek ki maguk elé (ESZAK, EK, Euratom, EFTA, KGST). Ezek az Európai Integráció kivételével nem tudták, és talán nem is akarták meghaladni a szabadkereskedelmi együttmüködést. Napjainkban a globális világgazdaság kialakulásának következtében a világgazdaság integrált rendszernek tekinthető, melyben az egyes nemzetgazdaságok nem függetleníthetik magukat a rendszer egészétől csak súlyos következmények árán. Egy ilyen rendszerben a különböző részegységek, azaz az egyes nemzetgazdaságok kölcsönösen függnek egymástól. Ez tulajdonképpen azt jelenti, hogy a nemzetállamok működését, létét más államok müködése, létezése számos igen változatos területen befolyásolja. Az egyes nemzetállamok céljaikat csak a többi állam létezésének és hatásainak számításba vételével valósíthatják meg mind gazdasági mind politikai értelemben (Simai 1985). Ebből a szempontból a „kölcsönös függésen keresztül adott országok fejlődése egyensúlyviszonyai, gazdasági stabilitása és teljesítménye a közösségi partnerkapcsolatoktól válik meghatározottá" (Palánkai 2011:85). A kölcsönös függés következtében a különböző 
országok nem függetleníthetik magukat egymástól, így a gazdasági integrációk nem csak gazdasági, de politikai dimenzióval is rendelkeznek.

Az integrációs tömbök nem csupán gazdasági alapokon jöhetnek létre, illetve az EU fejlődéséből következtethetünk arra, hogy a gazdasági együttmüködés az integrációnak csak egy állomása. Abból a tagok tovább léphetnek akár a politikai unió szintjére is. Eszerint a fölfogás szerint az integráció elsődleges célja a tagok közötti a gazdasági és politikai kapcsolatok megerösítése egy előre kitüzött cél elérése érdekében (Lacoste 2003). Ez a cél lehet gazdasági, de más természetű is. Jó példa erre az európai integráció, mely esetében az alapító államok a gazdasági fejlődés célkitüzése mellett a lakosság számára megfelelő életszínvonal biztosítását, vagy a béke hosszú távú fenntartásának célját is kitüzték maguk elé.

Az integrációs tömörülések különbözők lehetnek eszmeiségükben, ezáltal abban is, hogy milyen mélységben képzelik el az integráció kialakítását. A két klasszikus véglet a nemzetekfelettiség és a kormányköziség. A kormányköziség képviselői másnéven a „nemzetek” vagy „hazák integrációját" képviselik, véleményük szerint az integrációk fenntartásához elég egy minimális intézményesülés. Ez az állásfoglalás tulajdonképpen Charles de Gaulle nemzetek vagy hazák Európájának feleltethető meg. A tagok a kormányközi együttmüködésen nem lépnek túl, a tagállamok a szuverenitásuk minimális részéről mondanak csak le. A nemzetekfelettiség képviselői a föderalisták elképzelésük szerint az integráció tagállamainak föderációban, azaz szövetségi államban, teljeskörü politikai unióban kell egyesülniük. A szupranacionalizmus korai, a Közösség fejlődését megalapozó képviselöi Robert Schuman és Jean Monnet. A föderációban a törvényhozás, a döntéshozatal nemzetek feletti szintre kerül. Korunk legsikeresebb integrációs tömörülése, az Európai Unió a két véglet közül bizonyos nézőpont szerint egyiket sem, de tulajdonképpen mindkettőt megvalósította. Igy az Európai Közösség az integráció müködőképességének érdekében mindkét irányzat vívmányait beépítette az együttmüködésbe. Ez tulajdonképpen a Paul-Henri Spaak által képviselt funkcionalizmus vagy továbbfejlesztett változatának, a neofunkcionalizmusnak a megvalósulása. Ennek az alapvetően politikamentes megközelítésnek az alapja a csoportérdek, mely a közösségi érdeket meghatározza. Ott kell létrehozni múködőképes együttműködést, ahol a lehető legkisebb vagy kizárható a konfrontáció veszélye (A. II. világháború utáni Európában a béke megtartásának igénye, majd az Európai Szén és Acél Közösség létrejötte). Eszerint az általános megközelítés alapján az egy-egy ágazatban megvalósuló integráció a kiindulópont, mivel a különféle ágazatokban létrejött kooperáció tovagyürűző hatást fejthet ki más ágazatokra, így kiszélesítve az együttmüködés körét (Európai Szén és Acél Közösség, majd Európai Gazdasági Közösség). Széleskörübben értelmezve az együttműködés, mely a gazdasági csoportérdekből indul ki, átterjedhet nem gazdasági jellegü területekre is így mélyítve el az integrációt a tagok között (Európai Unió). Ez a folyamat bevonhat az együttmüködésbe olyan területeket is, melyeket az integráció kezdeti szakaszában még nem feltétlenül szerettek volna közösségi irányítás alá helyezni (pl. bizonyos politikai és szociális területek).

A jelenleg sikeres integrációs tömörülések mind a bipoláris világrend időszakában jöttek létre. Olyan időszakban, amikor két világrend állt egymással szemben. A nagyhatalmak a világuralomért folytatott harcot diplomáciai-katonai eszközökkel és csak másodsorban gazdasági eszközökkel kívánták megvívni. Illetve a gazdasági erő inkább kiszolgálója, erőforrása, mintsem eszköze volt a konfliktusok rendezésének. Ugyanakkor a 90-es években geopolitikai szempontból átalakult a világ. A kétpólusú világrend fölbomlásával és a globális világgazdaság 
kiteljesedésével a gazdasági erő felértékelődött a katonai csapásmérő erővel és a diplomáciai manőverekkel szemben. Ahogy Edward Luttwak fogalmaz a modern geopolitika korából a geoökonómia korába léptünk (Luttwak 1990). Ebben az új korszakban a geoökonómia időszakában, ha a diplomáciai út nem vezet kielégítő eredményre, a nagyhatalmak az egymás közötti nézetkülönbségeket gazdasági eszközökkel próbálják meg rendezni. Ha elfogadjuk Luttwak megállapítását - annak ellenére, hogy a geoökonómia mint önálló terület meglehetősen ellentmondásos megítélés alá esik (Babić, 2008; Bernek 2018) - akkor gazdasági integrációkat meghatározó geoökonómiai eszközöknek tekinthetjük a globális világgazdaságban. Eszerint az együttmüködések segítségével az egyes államok, vagy még inkább a kisebb érdekérvényesítő képességgel rendelkező államok céljaikat, véleményüket erőteljesebben tudják képviselni, akaratukat sikeresebben tudják érvényre juttatni (pl. BeNeLux államok, Kelet-Közép-Európa közepes nagyságú államai), legyen az regionális konfliktus vagy akár totális gazdasági háború (LOROT 1999). Emellett a gazdasági integrációk tagállamai közösen ellenállóbbak a különböző válságokkal, világgazdasági sokkokkal szemben. Kelet-Közép-Európában, az integráció geoökonómiai értelemben jelenleg a válságkezelés eszköze, de ez igaz az egész Közösség tekintetében is. Ám az Európai Unió a jelenlegi Ukrajnát érintő regionális konfliktus esetében, a gazdasági szankciókon keresztül az integrációt már, mint érdekérvényesítő eszközt használja mivel közösen próbál föllépni Oroszországgal szemben.

\section{A kelet-közép-európai államok és az európai integráció viszonyának alakulása}

A rendszerváltozás időszakában a volt szocialista kelet-közép-európai országok az európai integrációban látták a történelmi gazdasági lemaradásuk megváltoztatásának egyik leghatékonyabb eszközét. Az Európai Unió integrációs tömörülésként egyedülálló. A Közösség a gazdasági integráció szintjét meghaladta és az integráció nem gazdasági dimenzióinak köszönhetően problémákkal küzd. Ám ennek ellenére az európai szolidaritás és gazdasági együttműködés óriási jelentőséggel bír a térség államai számára és nem csak számukra, de a tágabb értelemben vett Európa számára is. A válsággal küszködő tagállamok esetében az EU számos esetben igen stabil pontnak tekinthető a problémák megoldásában.

A kelet-közép-európai államok integrációhoz kapcsolódó viszonyában öt jól elkülöníthető időszakot különböztethetünk meg:

A kelet- és közép-európai államok és a Közösség viszonyában az első szakasz az 1940-es évek végétől egészen az 1980-as évek végéig tartott. A szocialista blokk országai ebben az időszakban nem tekintették potenciális partnernek az Európai Közösség államait. Igaz ugyan, hogy érdeklődtek a nyugat-európai integráció sikerességének kutatása iránt. ám a két világgazdaság illetve az ideológiai szembenállás következtében kapcsolatfelvételről szó sem lehetett. Különösen azért, mert a két együttműködésre a kölcsönösen hủvös, olykor ellenséges viszony volt jellemző (Palánkai 1981). Erre csak az 1980-as évek végén kerülhetett sor, a rendszerváltozás időszakában. Ebben az időszakban a kelet-közép európai országokban az integrációnak kizárólag a szocialista fölfogása volt elfogadható (Golobics 2002). A térség országai számára a KGST létrehozása jelentette a gazdasági-politikai együttmüködés keretét. Ez az együttmüködés meglakolásakor tulajdonképpen a népgazdasági tervek összehangolásáról, de a szocialista országok közötti gazdasági kapcsolatok erősítéséről és a fejletlenebb tagállamok felzárkóztatásáról szólt (Horváth 2011). Valódi integrációs tömörüléssé nem válhatott mivel nem volt sem nemzetek feletti intézményrendszere, sem önálló jogalkotási hatásköre illetve nem 
hozhatott a tagállamok számára kötelező intézkedéseket. A szervezet által hozott döntések sokszor csak ajánlások voltak melyeket a tagállamok illetékesei vagy figyelembe vettek vagy nem. Ebben az időszakban a KGST feladata a szocialista blokkban tulajdonképpen a tábor egyben tartása volt gazdasági szempontból úgy, ahogy a Varsói Szerződés katonai szempontból tartotta össze a közösséget. Természetesen egyik szervezet kialakítása sem volt önkéntes, a Szovjetunió nyomására jöttek létre, ezt bizonyítja az a körülmény, hogy a Szovjetunió bukása után mindkét szervezet megszünt létezni. A KGST-ről azonban elmondható, hogy ugyan erősítette a szocialista tábor államai közötti kölcsönös függést, ám tény az, hogy ebben az időszakban szocialista integrációs szervezetként a Szovjetunió geoökonómiai eszköze a hatalma fenntartásához a térségben, melyet természetesen katonai eszközökkel is megvédett, ha az események megkívánták (Brezsnyev-doktrína alkalmazása: 1956, 1968) (Fischer 1992).

Ezt az időszakot a második, 1989-től 1994-ig tartó szakasz követte, amikor a rendszerváltó szocialista országok az integrációban látták a fejlődés lehetőségét. Ekkor történik meg a kapcsolatfelvétel a KGST és az EK között az 1988-ban Luxemburgban aláírt közös nyilatkozat alapján (Losoncz 1999). 1990-től tárgyalások kezdődnek a Közösség és a volt szocialista államok között, melyek következtében utóbbiak kereskedelmi megállapodásokat kötnek az EK-val. E korszak végének a társulási szerződések aláíását és a csatlakozási kérelem benyújtását, azaz a tagság iránti igény realizálódását tekinthetjük. A rendszerváltozás utáni az időszakban kiemelkedően fontos volt a PHARE (Pologne/Hongrie: Assistance à la Restructuration Économique) program, melyben a Közösség pénzügyi támogatást igyekezett nyújtani a kelet- és közép európai volt szocialista országok számára, hogy segítségükkel eljussanak abba a fejlődési szakaszba, melyben készek lesznek felvállalni az Unió tagságával járó kötelezettségeket (Hirschler - Kováts - Krekó - Kvassinger - Losoncz é.n.). A program létrehozása az 1989-es Párizsi G24 csúcson vetődött föl, és az azt szorgalmazó nyugati országok tulajdonképpen válasznak szánták a magyarországi és lengyelországi demokratikus gazdasági és politikai reformokra. A programot, mely világítótoronyként mutatta az utat Európa és az EK felé 1990-ben (Bulgária, Csehszlovákia, NDK, Románia, Jugoszlávia) és 1991-ben (Albánia, Észtország, Lettország, Litvánia) kiterjesztik a többi rendszerváltó országra is. Emellett 1990ben az EK a megindította az Európai Újjáépítési és Fejlesztési Bank megállapítását. A bank kialakításában a Közösség tagállamai és több a Közösségen kívüli állam mellett a volt keleti blokk közép- és kelet-európai országai is részt vettek. 1991-ben a már megkezdett tárgyalásoknak köszönhetően aláírják az első társulási megállapodásokat Magyarországgal, Lengyelországgal és Csehszlovákiával, 1993-ban Bulgáriával és Romániával, 1995-ben Észtországgal, Lettországgal és Litvániával, 1996-ban Szlovéniával ezek az új típusú társulási megállapodások, melyeket európai megállapodásoknak is neveznek (eu.eu). A megállapodások Magyarországgal és Lengyelországgal 1994-ben, Csehországgal, és Szlovákiával, Romániával és Bulgáriával 1995-ben lépnek életbe (Losoncz 2011). E társulási megállapodások, bár az addigi társulási szerződésektől különböztek, mégsem tartalmazták a tagság ígéretét, de kétség kívül az ahhoz vezető út első fontos állomásának tekinthetők (Balázs 2003). A volt KGST tagállamok az EFTA-val is folytattak tárgyalásokat és több megállapodást is kötöttek az EFTA országokkal, emellett az EK és az EFTA-val kötött megállapodások mintájára, bizonyítandó az integráció irányában való elkötelezettségüket, létrehozták a CEFTA-t, azaz a Közép-európai Szabadkereskedelmi Megállapodást. A CEFTA, melynek alapításáról Lengyelország, Csehország, Szlovákia és Magyarország 1992-ben Krakkóban aláírt szerződés alapján állapodott 
meg, 1994-ben lépett hatályba. Szlovénia 1996-ban, Románia 1997-ben Bulgária 1999-ben, Horvátország 2003-ban csatlakozott az együttmüködéshez. A megállapodás, mely bizonyos szempontból a volt KGST tagállamok közötti kereskedelmet segítette elö és annak megszünésével keletkezett ürt is betöltötte a volt tagok között, valamennyi ipari és mezőgazdasági termékre kiterjedt. Az időszakban egyértelművé vált a közép-, és kelet-európai volt szocialista államok elkötelezettsége az integráció irányába ezt a társulási megállapodások aláírása, és a CEFTA létrehozása is alátámasztotta. A kapcsolatfelvétel és a társulási megállapodások megkötése már előre vetítette, hogy a térség országai hosszú távon a Közösség tagjaivá kívánnak válni. A Szovjetunió és a bipoláris világrend megszünése illetve a demokratikus politikai és gazdasági átalakulás, a piacgazdaság kiépítésének megkezdése, majd a rendszerváltozás kiteljesedése elhárította a mintegy négy évtizeden keresztül fennálló akadályokat a térség európai, sőt euróatlanti integrációja elöl.

A következő időszakban az 1994 és 2004-közötti időszakban a társult tagállamok egymás után nyújtják be a csatlakozási kérelmeiket (Horváth 2011). A Közösség már az 1993-as Koppenhágai ET csúcson nyilvánvalóvá tette, hogy a Kelet-Közép-Európai Államoknak bizonyos feltételek teljesítése esetén felajánlják a csatlakozás lehetőségét. Ezek a később Koppenhágai Kritériumoknak nevezett feltételek a következők voltak: Stabil demokratikus intézményrendszer, jogállamiság, emberi jogok tényleges érvényesülése, kissebségek védelme és jogaik tiszteletben tartása. Múködő piacgazdaság, mely képes megbirkózni az Uniós piaci versennyel. Képesség a tagságból adódó kötelezettségek teljesítésére, az acquis communautaire átvétele és alkalmazása, a politikai és monetáris unióhoz való csatlakozás. Emellett természetesen a Közösségnek is készen kellett állnia a bővítésre. 1994-ben elsőként Magyarország nyújtotta be tagság iránti kérelmét, majd hazánkat sorban követték a térség országai. Ugyanebben az évben Lengyelország, majd 1995-ben Románia, Szlovákia, Lettország, Észtország, Litvánia Bulgária, 1996-ban Csehország és Szlovénia (Törökország már 1987-ben, Ciprus és Málta 1990-ben benyújtotta csatlakozási kérelmét). A legfelkészültebb államokkal kapcsolatban az 1997-es luxemburgi csúcson határoztak arról, hogy 1998-ban megkezdik a csatlakozási tárgyalásokat. E tagjelöltek Lengyelország, Csehország, Magyarország, Szlovénia, Észtország és Ciprus. Velük kapcsolatban azt is meghatározták, hogy a csatlakozás legkorábbi dátuma 2002 utánra fog esni. A többi tagságért jelentkező tagállam esetében a tagjelölt státusz megadása mellett döntöttek, de a tárgyalások megkezdésének időpontjára nem tettek javaslatot. Az 1999-es Helsinki csúcson az ET döntött arról, hogy az Unió csatlakozási tárgyalások folytatását kezdeményezi újabb 6 tagjelölt esetében. Bulgáriával, Lettországgal, Litvániával, Romániával és, Szlovákiával 2000-ben kezdték meg a csatlakozási tárgyalásokat, valamint kimondták azt, hogy az EU 2003-ra kész volt a bővítésre és addigra szeretné lezárni a csatlakozási tárgyalásokat a tagságra alkalmas tagjelöltekkel, ám a csatlakozás pontos dátumát a tagországok egyéni felkészültsége alapján határozták meg. A csatlakozási útiterv szerint a csatlakozás legkorábbi időpontja a legfelkészültebbek esetében 2004 lehet. 2002-ben az Európai Tanács Koppenhágai ülésen lezárulnak a csatlakozási tárgyalások a 10 tagjelölttel, majd 2003. április 16.-án Athénban a 10 csatlakozásra váró ország aláírja az európai uniós csatlakozási szerződést, mely 2004. május 1-én lépett hatályba. Lezárult tehát Európa bő 40 éves kettéosztottságának fejezete. A bővítést természetesen geostratégiai megfontolások is vezették. A térség stabilitását hosszú távon Kelet-Közép-Európa országainak gazdasági stabilitása, fejlődése biztosíthatja. Erre ideális eszköz volt az Európai Unió integrációjához való csatlakozás. Mind az 
EU tagállamai, mind a kelet- és közép-európai államok részéről az integráció hatásos geoökonómiai eszköznek bizonyult céljaik eléréséhez. Elöbbieknek a térség stabilitása utóbbiaknak gazdasági-társadalmi fejlődéshez, a jólét növeléséhez. Kelet-Közép-Európa országai számára ebben az időszakban az uniós tagság elnyerése nemcsak a stabilitást és a fejlődést jelentette, a fejlett nyugathoz való csatlakozást jelentette. A tagság egyfajta demokrácia és értékfogalommá vált. A keleti bővítés pedig számukra a második világháború után akaratuk ellenére kialakult megosztottság végét is jelentette Európában. Ezzel is magyarázható, hogy a tagjelöltek nemcsak a csatlakozási tárgyalások, de a tagságuk első időszakában is feltétel és jelentősebb kritika nélkül elfogadták azokat a vívmányokat, illetve azt az értékrendet, melyet a Közösség tagállamai képviseltek. Így az integrációt és az Európai Uniót mindenképpen pozitív eszköznek tekintették céljaik elérése kapcsán. A 90-es évek második felében Oroszország már nem jelentős befolyásoló tényező a térségben, az általa hagyott ürt, ha nem is vállaltan, de a Közösség kívánta betölteni, ezzel is stabilizálva Európa ezen részét geopolitikai szempontból. A térség államai pedig szabadon saját elhatározásukból csatlakozhattak a Közösséghez.

A 2004-es, majd a 2007-es bővítéssel (melyben a 2004-es bővítési körből kimaradt Románia és Bulgária is csatlakozott az EU-hoz) a térség országai csatlakoztak az európai centrumhoz. A bővítések egyértelmúen az Európai Unió sikerességét bizonyítják. A Közösség bebizonyította, hogy képes a megújulásra és a reformra. És nem mellesleg a bővítés folyamata mellett az integráció mélyítésének folyamatát is tovább tudták vinni, egy olyan időszakban, amikor a reform folyamatosan napirenden volt. (Ezt bizonyítja az Alkotmányszerződés 2005-ös bukása után 2007-ben elfogadott és 2009-ben hatályba lépett Lisszaboni-szerződés, mely megreformálta a Közösséget). Tény az, hogy a Közösség ebben az időszakban is küzdött problémákkal, ám elmondható, hogy a 2004 és 2010 közötti időszak sikeresnek tekinthető. Abból a szempontból mindenképpen, hogy az időközben jelentkező problémákra a Közösség, ha esetleg megkésve is, de kielégítő válaszokat tudott adni. Még akkor is, ha a 2004-es és a 2007-es bővítés az EU 15-ök fejlettségi átlagánál fejletlenebb tagok csatlakozásával újabb terheket rótt a Közösség fejlettebb tagállamaira. E terheket mindenképpen enyhítette az egységes belső piac kiszélesedése, mely immár 500 milliós európai piacként a világ egyik legnagyobb gazdasági terévé vált és hozzájárult az EU versenyképességének növeléséhez (Horváth 2011). Az Európai Unió számára a kelet-közép-európai térség a belső piac integráns részeként nagy jelentőséggel bír, mivel a bővítés új lendületet adott a gazdasági növekedésnek. Kétségtelen tény hogy nem csak a csatlakozó államok, de a többi tagország is profitált a bővítésből, hiszen az új tagállamokkal folytatott egyre bővülö kereskedelem, illetve az e tagállamokban eszközölt befektetések éves szinten közel 0.5\%-al bővítették a gazdasági növekedést a 2004 elött csatlakozott tagállamokban (Az Európai Unió hivatalos honlapja). A kelet- és közép európai államok számára a 2004-2010 közötti időszak a beilleszkedés és a minden tekintetben teljes jogú taggá válás időszaka. Az új tagállamok csatlakozásuknak köszönhetően jelentős fejlődésen mentek keresztül. A térség országai az egységes belső piachoz való csatlakozásuknak köszönhetően az addigi félperifériális helyzetükből átkerültek az európai centrumtérségbe. A regionális különbségek, ahogy 2004 előtt az EU 15-ök esetében is, természetesen megvannak, ám csökkentésükhöz ebben az időszakban jelentősen hozzájárult az Európai Uniós tagság és az abból következő regionális politikai támogatások egész sora. Meg kell azonban jegyezni, hogy a térség államaiban meglévő regionális különbségek, melyeket, ha nem kezelnek kielégítően, később komoly veszélyeket rejthetnek magukban. A jelentős regionális különbségek okozta problémák 
súlyosságával a fejlettebb tagállamok is tisztában vannak. Ezért a nyugat-, és észak-európai fejlettebb területek és a kelet-közép, illetve a kelet európai területek közötti gazdasági-, életszínvonalbeli különbség kérdése a legfontosabb megoldandó problémák egyike az Európai Unión belül. A tagállamok tudatában vannak, hogy ez a későbbiek során komoly feszültségforrássá válhat a tagállamok között. A probléma megoldását segíti az is, hogy KeletKözép-Európa kis és közepes nemzetgazdaságai integrálódtak az egységes belső piacba, mely által megszüntek a tagállamok gazdaságait elválasztó határok és a négy alapszabadság érvényesülésével ezen országok gazdasági szereplői az egész európai piacon müködhetnek, ezáltal kiszélesítve lehetőségeiket. Az új tagok élvezik a tőkeerősebb nyugat-európai országok befektetéseiből illetve az európai multi- és transznacionális vállalatok tevékenységéből származó előnyöket is, ezáltal mérsékelve a regionális különbségeket. Összességében elmondható, hogy a közös fellépésnek köszönhetően ezen országok érdekérvényesítő képessége jelentősen nőtt mind gazdasági, mind egyéb (diplomáciai, politikai) területeken és a kelet-közép-európai államok egyértelmüen profitáltak a tagságból (Tőkés 2017).

A 2007-2011-es válság (Losoncz - Nagy 2011.) következtében felszínre kerültek azok a problémák, melyek újabb reformok szükségességét, illetve bizonyos szakpolitikák finomhangolását vagy átalakítását kívánták meg (Moldicz 2012). Kétségtelenül igaz az, hogy a változtatásra irányuló igényeket illetve az időszakban kialakult a tagállamok közötti véleménykülönbségeket ezen átalakításokkal kapcsolatban és az unió későbbi fejlődé sét illetően külső és belső tényezők egyaránt indukálták (Pl: 2007-2011-es pénzügyi válság, globális migrációs folyamatok, BREXIT, az állami és EU-s intézményekből való kiábrándulás és bizalmi válság, a további mélyítés és bővítés kérdése valamint a reformfolyamat megrekedése). Így elmondható, hogy a 2010 és 2018 közötti időszak az Európai Unió müködésével, jelenlegi állapotával és későbbi fejlesztésével kapcsolatos első kritikák időszaka a kelet-közép-európai államok részéről. A térség államai bizonyos kérdéseket másként ítélnek meg, mint a 2004-előtt csatlakozott tagállamok (2007-2011-es válság megoldása, globális migrációs helyzet megoldása, további bővítés, reformok kérdése). A vitát kiváltó területek hagyományosan nem a gazdasági együttmüködés részét képezik, ám annak müködése e területek nélkül kevésbé lenne hatékony. Az sem igaz, hogy e területekkel kapcsolatban 2010 vagy 2004-előtt nem voltak komoly viták a tagállamok között. Ám e vitákban a kelet-közép európai államok nem vettek részt olyan markánsan illetve olyan egyes területeket érintő sajátos véleményekkel, mint 2010 után. A kilencvenes évektől a tagállamok közötti együttmüködés új területekkel bővült, így ma már elmondható, hogy napjainkban már nem csak gazdasági integrációként hangsúlyos. A tagállamok a gazdasági együttműködést már megkerülhetetlen alapnak tekintik. Ám e gazdasági együttmüködés mellett a szolidaritás és a politikai integráció mélyítése egyre jelentősebb kérdéssé vált (Tőkés 2017). A kelet-közép-európai országok sajátos fejlődése és a szocializmus örökségeként máig meglévő különbségek következtében ezen országok esetében alternatív vélemények jelentek meg az együttmüködés gazdaságon kívüli területeinek tovább fejlesztésével, illetve az Unión belüli szolidaritás értelmezésével kapcsolatban. Kelet-Közép-Európában egyre hangsúlyosabban jelentkezik a „több nemzetállam kevesebb EU” gondolat a politikai integráció szintjén, ez a hozzáállás a legtöbb esetben nem feltétlenül jelenti az integráció fejlesztésének elutasítását, csak a hagyományos mélyítési próbálkozások kritikai értékelését (Tőkés 2017). 


\section{Konklúzió}

Összességében elmondható, hogy a kelet-közép-európai államok a kritikusabb hozzáállásuk dacára még mindig igen fontosnak tartják az Európai Unió megerősítését. A térség államai illetve a többi Európai Uniós tagállam véleménye között az integráció geoökonómiai megítélésben nincs jelentős különbség. Mint minden Európai Uniós tagállam Európa világgazdasági szerepének versenyképességének megörzésében illetve erősítésében a gazdasági integrációnak kiemelt szerepet tulajdonítanak. A belső piac, a tagállamok közötti kohézió erősítését, illetve a gazdasági integráció továbbfejlesztését Európa hosszú távú felemelkedésének tekintetében az egyik legjelentősebb eszközként veszik számításba. Ahhoz azonban, hogy az integráció használható geoökonómiai eszközként működhessen, szükség van a reformra. Ez ebben az esetben az integráció további mélyítését jelentheti. Azaz a „több Európa kevesebb nemzetállam” elv erőteljesebb érvényesülését. Ennek elősegítésével kapcsolatban a tagállamok tevékenységének szorosabb összehangolása is kívánatos lenne, ám ehhez a tagok között teljes egyetértésre van szükség. Az integráció további mélyítését támogató álláspontok, melyek szerint a tagállamoknak további hatásköröket kellene leadniuk a Közösség számára, inkább a keleti bővítés előtt belépő tagállamok körében népszerủek. Ezzel az elképzeléssel viszont a kelet-közép-európai államok egy része nem ért egyet. E tagállamok véleménye szerint a megoldás pont e koncepció ellentéte. Azt az álláspontot képviselik, mely szerint a gazdasági integráció müködhet a kiegészítő politikák további mélyítése nélkül is. Tehát a Közösségen belül a gazdasági együttmüködés legyen a hangsúlyosabb, a politikai integráció csak olyan mértékig mélyüljön, amilyen mértékben azt a gazdasági integráció föltétlenül megkívánja. Elképzelésük szerint így is megfelelően lehet irányítani és kihasználni az integrációban meglévő lehetőségeket a versenytársakkal szembeni előnyök kiharcolásához. Ez a már említett „kevesebb Európa több nemzetállam” elv érvényesülését jelentené. Felvetődik a kérdés, hogy mélyíthető-e a gazdasági integráció úgy, hogy a politikai integrációt nem fejlesztik tovább vagy esetleg bizonyos területeken visszafejlesztik? Az erre a kérdésre adott válasz azért fontos, mivel e tagállamok a gazdasági együttmüködés szorosabbra füzésének szándékával egyetértenek. Ám egyes keletközép-európai államok szerint a térség történelmi örökségének köszönhetően más igényekkel rendelkezik, mint akár az EU 15-ök és még nem képes úgy érvényesíteni érdekeit, ahogy azt ezen örökség feloldása megkívánná. Éppen ezért bizonyos területeken (menekültkérdés, bevándorlás, regionális politika) szükséges a térség államainak közös fellépése, és e fellépéssel kapcsolatos egyeztetés. A Visegrádi-Négyek azaz Lengyelország, Csehország, Szlovákia, Magyarország együttműködése lehet a keret ezekre az egyeztetésekre, egy esetleg kibővített Visegrádi Csoport 6 esetleg 7 tagállammal. E regionális együttmüködés múködhetne ellensúlyként a kelet-középeurópai álláspontok hangsúlyosabb képviselete érdekében. E kibővített együttmüködés akkor lehet sikeres, ha a politikai egymásrautaltságon kívül jelentkezik más esetleg gazdasági-, társadalmi alapokon nyugvó közös érdek az együttmüködés országai között. A közös európai szintű fellépés igénye azonban azt is mutatja, hogy az utóbbi időben módosult ugyan az integráció megítélése a térség országaiban ám integrációpárti hozzáállásuk nem változott.

Az Európai Unió jelenleg nem csupán gazdasági integrációnak tekinthető. Az együttmüködés más területeken is sikereket ért el, éppen ezért a Közösséget ,jóléti integrációnak” is tekinthetjük, annak minden pozitív és negatív következményével. Az EU jelenlegi problémáit nem a gazdasági együttmüködés, hanem az azt kiegészítő, támogató területek integrálásának 
köszönheti. Ám a gazdaság ilyen fokú integrálódása, melyet Európa versenyképességének a megőrzése is megkíván, szükségessé teszi e területek közös irányítás alá vonását. A tagállamok azonban nem értenek egyet abban, hogy ez a közös irányítás és a tagállami kompetenciák leadása meddig kell hogy terjedjen. A Bizottság „Európa jövőjéröl” című fehér könyvében foglalkozik az integráció további fejlődésével, ezzel is ösztönözve a különböző nézeteket képviselő tagállamokat álláspontjaik közelítésére.

E kérdés és a két integrációval kapcsolatos álláspont - a „több Európa kevesebb nemzetállam”, és a „több nemzetállam kevesebb Európa”- közötti szembenállás feloldása jelenleg az Európai Unióval kapcsolatos viták egyik legfontosabb területe. A tagállamoknak közösen, együttműködésben egymás véleményének és álláspontjának kölcsönös tiszteletben tartásával kell rá megoldást találniuk.

\section{Irodalomjegyzék}

1. Babić, B. S. 2008: Geo-economics- Reality \& science Scientific review paper Faculty of Geoeconomics, Megatrend University, Belgrade

2. Balassa B. (1961): The theory of economic integration. Homewood, III., R.D. Irwin

3. Balázs P.(2003): Az Európai Unió külpolitikája és a magyar-EU kapcsolatok fejlődése. KJKKerszöv Jogi és Üzleti Kiadó Kft. Budapest. 2003. p. 517

4. Bernek Á. (2018): Közép- és Kelet Európa a 21. század geopolitikai/geoökonómiai stratégiáiban. Akadémiai Kiadó. Budapest. p.200

5. Hirschler A. - Kováts K. - Krekó L. - Kvassinger K. - Losoncz M. (é.n.): A Phare segélyprogram Magyarországon. Külügyminisztérium-ITD Hungary. p.190.

6. Horváth Z. (2011): Kézikönyv az Európai Unióról. HVG-Orac Kiadó, Budapest. p.681

7. Lacoste, Y. (1993): Dictionnaire de géopolitque, Flammarion. Paris

8. Lorot, P. (1999): La nouvelle grammaire des rivalités internationales. In: Lorot, P. (szerk): Introduction à la géoéconomie. Ed. Economica. Paris

9. Losoncz M. (1999): Nyugat-Európai Integráció. Modern Üzleti Tudományok Főiskolája-TriMester Bt. Tatabánya p.216

10. Losoncz M. (2011) Az Európai Unió külkapcsolatai és külkapcsolati politikája. Tri Mester Bt., Tatabánya. 239 oldal.

11. Losoncz M.-Nagy Gy. (2011): A globalizáció és a 2007-2011. évi pénzügyi válság. Tri Mester Bt., Tatabánya. p.235

12. Luttwak, E. N.: (1990): From Geopolitics to Geo-Economics: Logic of Conflict, Grammar of Commerce. National Interest. 20, pp 17-24

13. Moldicz Cs. (2012): A változó Európai Unió. Válságról válságra. Typotex Elektronikus Kiadó Kft. Budapest. p.210

14. Palánkai T.(1981): A nyugat-európai integráció. Közgazdasági és Jogi Könyvkiadó. Budapest. p. 273

15. Palánkai T. (2011): A nemzetközi integráció értelmezései. - In: Palánkai T-Kengyel Á. Kutasi G. -Benczes I. -Nagy S. Gy. (szerk.): A globális és regionális integráció gazdaságtana. Akadémiai Kiadó. Budapest. pp.76-90.

16. Perroux F.(1954): Europe sans rivages Presses Universitaires de France Paris p.668

17. Simai M, (1985): Hatalom-Technika-Világgazdaság. Budapest. KJK

18. Fischer F. (1992): A megosztott világ - A Kelet-Nyugat, Észak-Dél nemzetközi kapcsolatok fó vonásai (1945-1989). IKVA Kiadó, Budapest. p.390

19. Fehér Könyv Európa jövőjéröl. A 27 tagú EU útja 2025-ig: gondolatok és forgatókönyvek EB. 2017 (https://ec.europa.eu/commission/sites/beta political/files/feher_konyv_europa_jovojerol_hu.pdf)

20. Tőkés T. (2017): A gazdasági integrációk szerepe Kelet-Közép-Európa geoökonómiai jelentőségének alakulásában a rendszerváltástól napjainkig. a 2017. augusztus 25-én Sopronban megtartott Geopolitikai Konferencia (Geopolitikai Konferencia Közép- és Kelet- 
Régiókutatás Szemle 2019. 1. sz.

DOI: $10.30716 / \mathrm{RSZ} / 2019 / 1 / 7$

Európa a 21. század többpólusú világában), tanulmányait tartalmazó kötet (alkotó-szerkesztő Dr. Bernek Ágnes) számára készült tanulmány-kézirat.

21. Az Európai Unió hivatalos honlapja (www.europa.eu.). Európai Bizottság: Bővítési politika. Az európai értékek és normák kiterjesztése más országokra. ISBN: 978-92-79-49197-9. Európai Bizottság- Kommunikációs Főigazgatóság p.11 https://publications.europa.eu/hu/publication-detail/-/publication/5c93a9e3-f5b7-4567-88aaeaa55451a0a1

22. https://europa.eu/european-union/about-eu/history/1990-1999/1991_hu

23. Golobics P. (2002): A nemzetközi gazdasági integrációk -integrációföldrajzi körvonalak pp. 191-209 in. Tóth J. (szerk.): Általános Társadalomföldrajz II. kötet. Dialog Campus. Budapest-Pécs 